\title{
Comparison of Heterobasidion Insulare with white rot fungi in Degradation wastewater of Pesticide plant
}

\author{
Yue Li-Hong ${ }^{1,}$, Wang Yu-Jun ${ }^{2, b}$ and Zhang Yue-Hua ${ }^{3, c^{*}}$ \\ ${ }^{1.2}$ Jiamusi University School of Life Sciences, Heilongjiang Province, China \\ ${ }^{3}$ Institute of Microbiology, University of Jiamusi, Heilongjiang Province, China \\ aemail:yuelihong64@163.com; 'email:wangyujun2011@163.com;'email: \\ $c^{*}$ zhangyaohua_2008@163.com
}

\begin{abstract}
Keywords: Heterobasidion Insulare; Laccase; Phenol; decolorizing; Degradation
Abstract. A Heterobasidion Insulare ability to degrade in different culture conditions was investigated and compared to that of P. chrysosporium. The results indicated that H.Insulare isolate is more efficient than P. chrysoaasporium in decolorizing in the presence of added nutrients. H.Insulare is able to remove more than 50\% of the color and phenols from Pesticide plant with in 6 days of incubation, whereas P. chrysosporium needs more than 12 days to reach similar results in the same conditions. Many factors affecting the treatment of diluted waste water of Pesticide plant (30\%) by H.Insulare were studied, including the effects of added nutrients, initial $\mathrm{pH}$, and temperature and inoculated biomass. Once the optimization of $30 \%$ waste water of Pesticide plant biodegradation process had been set up, higher waste water of Pesticide plant concentrations (50\%) were tested. The results show that the fungus is capable of reducing all parameters analyzed at least $60 \%$, after only 9 days of growth.
\end{abstract}

\section{Introduction}

Large amounts of pesticide is produced and used in China. Pesticide industry generates approximately 150 million tons of wastewater annually. Pesticide wastewater contains high concentrations of pollutants, the biological oxygen demand (BOD) and the chemical oxygen demand (COD) of this waste may be as high as $100 \mathrm{~g} / \mathrm{l}$ and $200 \mathrm{~g} / \mathrm{l}$, respectively; moreover, the concentration of phenolic and polyphenolic compounds can exceed $10 \mathrm{~g} / \mathrm{l}$. Most of the color of waste water of pesticide plant is due to the aromatic compounds that are present and which have phototoxic and antibacterial effects [1]. Many difficulties have been encountered during aerobic and anaerobic bacterial treatment processes of this waste; therefore the elimination of phenols from waste water of Pesticide plant is an important objective in order to reduce its toxicity and to permit the occurrence of microbial fermentation. Recently, potential applications of white-rot fungi and their enzymes are gaining increasing importance in the detoxification of industrial waste waters and of a vast range of xenophobic environmental pollutants [2]. A strain of H.Insulare has been reported to efficiently decolorize Pesticide wastewater only when cultures are flushed with pure oxy-gen and supplemented with verity alcohol as inducer of the ligninolytic system. Furthermore, it is reported that the P.chrysosporium mycelium is able to remove phenols and to detoxify $10 \%$ diluted waste water of Pesticide plant in the absence of any external added nutrient. Nevertheless, it has also been reported that the addition of simple or complex nutrient is essential in order to obtain an efficient decolonization. The present work was aimed at studying the ability of a white-rot fungus of $H$.Insulare, isolated from $H$. Insulare strain was isolated from fallen wood of Korean pine in forest of Xiaoxing'anling and classified as $H$. Insulare, to modify the polluting properties of diluted Pesticide wastewater in comparison with that of P.chrysosporium [3]. Optimal conditions for the utilization of P.chrysosporium in the treatment of Pesticide wastewater were also explored.

\section{Materials and methods}

Pesticide wastewater was collected from a pesticide factory, Jiamusi City, northeast China, centrifuged at 5,000 rpm for $10 \mathrm{~min}$ to eliminate solids and Insoluble matters, and stored at $-20^{\circ} \mathrm{C}$. Strain and culture conditions Two different fungal strains were used in the pesticide wastewater 
treatment experiments: a strain isolated using the agar plate technique and classified by PDA. Fungi were maintained through periodic transfer at $4^{\circ} \mathrm{C}$ on potato-glucose $(2.4 \%)$ agar plates in the presence of $0.5 \%$ yeast extract. Incubations in liquid medium of both fungi were carried out at $28^{\circ} \mathrm{C}$ in the dark by pre inoculating $300 \mathrm{ml}$ of potato-dextrose broth $(2.4 \%)$ containing $0.5 \%$ yeast extract in 11 shaken flasks with P. ostreatus or H.Insulare mycelia. After 5 days culture, samples of $25 \mathrm{ml}$ of culture were transferred into 11 flasks containing $250 \mathrm{ml}$ of different media [4]. Cultures were incubated at $28^{\circ} \mathrm{C}$ under continuous agitation (120 rpm).

\section{Enzyme assays}

Lignin peroxidase (LiP) activity was determined using vertebral alcohol as substrate. The assay mixture contained $2.0 \mathrm{mM}$ vertebral alcohol and $0.4 \mathrm{mM} \mathrm{H}_{2} \mathrm{O}_{2}$ in $50 \mathrm{mM}$ sodium titrate buffer, $\mathrm{pH}$ 2.5. Oxidation of vertebral alcohol was followed by measuring the absorbance increase at $310 \mathrm{~nm}$. Manganese peroxidase (MnP) activity was determined using $\mathrm{MnSO}_{4}$ as substrate. The assay mixture contained $0.5 \mathrm{mM} \mathrm{MnSO}_{4}$, and $0.5 \mathrm{mM} \mathrm{H}_{2} \mathrm{O}_{2}$ in $50 \mathrm{mM}$ sodium malamute buffer, $\mathrm{pH}$ 4.5. Oxidation of $\mathrm{Mn}_{2}{ }^{+}$to $\mathrm{Mn}_{3}{ }^{+}$was followed by measuring the absorbance increase at $270 \mathrm{~nm}$ due to the formation of $\mathrm{Mn}_{3}{ }^{+}$-malonate. Enzyme activity was expressed in IU. Laccase activity was determined using ABTS as substrate. The assay mixture contained $2 \mathrm{mM}$ ABTS in $0.1 \mathrm{M}$ sodium citrate buffer, $\mathrm{pH}$ 3.0. Oxidation of ABTS was followed by measuring the absorbance increase at $420 \mathrm{~nm}$. Enzyme activity was expressed in IU.

\section{Determination of phenol content}

Phenol concentration was determined by a colorimetric assay as described based on the oxidative coupling of phenol and 4-amino-antipyrine [5].

\section{Chemical analyses}

Analyses of $\mathrm{pH}$, suspended matter, chlorine $\left(\mathrm{Cl}^{-}\right)$, potassium $\left(\mathrm{K}^{+}\right)$, ammoniac nitrogen $\left(\mathrm{NH} 4^{+}\right), \mathrm{COD}$ were determined according to APHA standards methods [6].

\section{Results}

The composition of pesticide wastewater chemical characteristics of the crude waste used in this study is shown in Table1. The presence of the reported concentrations of polluting substances, particularly phenols $(12.0 \mathrm{~g} / \mathrm{l})$ and other organic compounds $(\mathrm{COD}, 50 \mathrm{~g} / \mathrm{l})$, noticeably reduces the ability of most micro organisms to grow on this waste. Treatment of pesticide wastewater by Pl.ostreatus and H.Insulare In order to study the effects of fungal treatment on pesticide wastewater, two different white-rot fungi were tested in batch cultures of diluted pesticide wastewater (20\%), supplemented with potato dextrose $(0.24 \%)$, yeast extract $(0.05 \%)$ and maltose $(1 \%)$. Both fungi are able to decolorise $20 \%$ pesticide wastewater in the presence of added nutrients; Pl. ostreatus and H.Insulare cause about $65 \%$ and $95 \%$ decrease of absorbance at $395 \mathrm{~nm}$, respectively, after 15 days of growth (Fig.1). It is worth noting that Pl. ostreatus is able to reduce more than $50 \%$ of the initial color after 6 days of incubation. Phenol content and COD decrease were also compared (Fig.2). The maximum reduction of phenol content and COD is $62 \%$ and $52 \%$ for Pl. ostreatus, whilst it is $82 \%$ and $77 \%$ for H.Insulare after 15 days of treatment. The time course of absorbance decrease is similar to that of phenol content and COD reduction for both fungi, suggesting the existence of a correlation between these parameters and the colored components present in pesticide-water.

\begin{tabular}{ll||ll}
\hline \multicolumn{4}{c}{ Table 1. Composition of wastewater of Pesticide plant } \\
\hline $\mathrm{pH}$ & 4.2 & $\mathrm{SM}(\mathrm{g} / \mathrm{l})$ & 4.00 \\
Colour $(\mathrm{A} 395)$ & 16.0 & $\mathrm{Cl}^{-}(\mathrm{g} / \mathrm{l})$ & 11.9 \\
$\mathrm{COD}(\mathrm{g} / \mathrm{l})$ & 50.0 & $\mathrm{~K}^{+}(\mathrm{g} / \mathrm{l})$ & 2.5 \\
Phenol $(\mathrm{g} / \mathrm{l})$ & 12.0 & $\mathrm{NH}_{+}^{+}(\mathrm{g} / \mathrm{l})$ & 0.15 \\
\hline
\end{tabular}

Note: COD chemical oxygen demand, SM suspended matter. 
The results obtained indicate that $H$.Insulare is able to decolorize pesticide wastewater and to degrade its phenolic component more efficiently than Pl.ostreatus of different parameters for pesticide wastewater treatment by H.Insulare. On the basis of the above results, H.Insulare was chosen to set up better conditions for pesticide wastewater biodegradation. For this purpose several parameters were analyzed, monitoring the events occurring after 6 days of fungal treatment. Different carbon sources were utilized to supplement $20 \%$ diluted pesticide wastewater in order to investigate their effect on colors, phenols and COD reduction during fungal growth. The best results were obtained using glycerol as an additional substrate. No significant difference was found between cultures grown in the presence or absence of added nutrients; therefore, the following experiments were performed with cultures in the absence of nutrients, thus taking into account this economic aspect for potential biotechnological applications. The mycelia of $H$.Insulare were grown in $20 \%$ pesticide wastewater at different temperatures $\left(20,28\right.$ and $\left.37^{\circ} \mathrm{C}\right)$ starting from mycelia originally grown at $28^{\circ} \mathrm{C}$ (Table 2 ).

Table 2. Colour, phenol removal and chemical oxygen demand (COD) and Colour by H.Insulare and P. chrysosporium

\begin{tabular}{lccccccc}
\hline Carbon source & $\begin{array}{c}\text { Colour } \\
\text { removal }\end{array}$ & $\begin{array}{c}\text { Phenol removal } \\
(\%)\end{array}$ & $\begin{array}{c}\text { COD } \\
\text { removal }\end{array}$ & $\begin{array}{c}\text { Incubation } \\
\text { temperature }\end{array}$ & $\begin{array}{c}\text { Phenol } \\
\text { removal (\%) }\end{array}$ & $\begin{array}{c}\text { Colour } \\
\text { removal (\%) }\end{array}$ & $\begin{array}{c}\text { COD } \\
\text { removal (\%) }\end{array}$ \\
\hline 20\% PW & 49 & 50 & 46 & 20 & 20 & 22 & 25 \\
20\% PW-PDYm & 65 & 64 & 59 & 28 & 49 & 47 & 45 \\
20\% PW-PDY & 58 & 60 & 54 & 37 & 28 & 30 & 29 \\
20\% PW-mal & 60 & 63 & 57 & 21 & 23 & 19 & 24 \\
20\% PW-glu & 63 & 67 & 61 & 22 & 25 & 23 & 23 \\
20\% PW-gly & 67 & 70 & 64 & 19 & 21 & 25 & 27 \\
\hline
\end{tabular}

Note: PW:means Pesticide wastewater

The highest decrease in colors, phenol content and COD was observed at $28^{\circ} \mathrm{C}$. The reduction of these parameters, determined at 20 and $37^{\circ} \mathrm{C}$, were similar and noticeably lower than that observed at $28^{\circ} \mathrm{C}$. Therefore $28^{\circ} \mathrm{C}$ was chosen as the incubation temperature for the following experiments.

The effect of the initial $\mathrm{pH}$ on the fungus' ability to degrade pesticide wastewater was explored in the $\mathrm{pH}$ range 3.0-7.0. The results show that cultures starting at $\mathrm{pH}$ values ranging from 4.0 to 5.0 lead to the most efficient removal of phenol, colors and COD (Fig.2). Different amounts of H.Insulare mycelia were also used as inoculums in treatment experiments of $20 \%$ pesticide wastewater. The results (data not shown) demonstrate that greater inoculate give faster decolonization up to $4.0 \mathrm{~g} / \mathrm{l}$ (inoculums dry weight/liter of medium) whilst no significant differences were observed after doubling this amount.
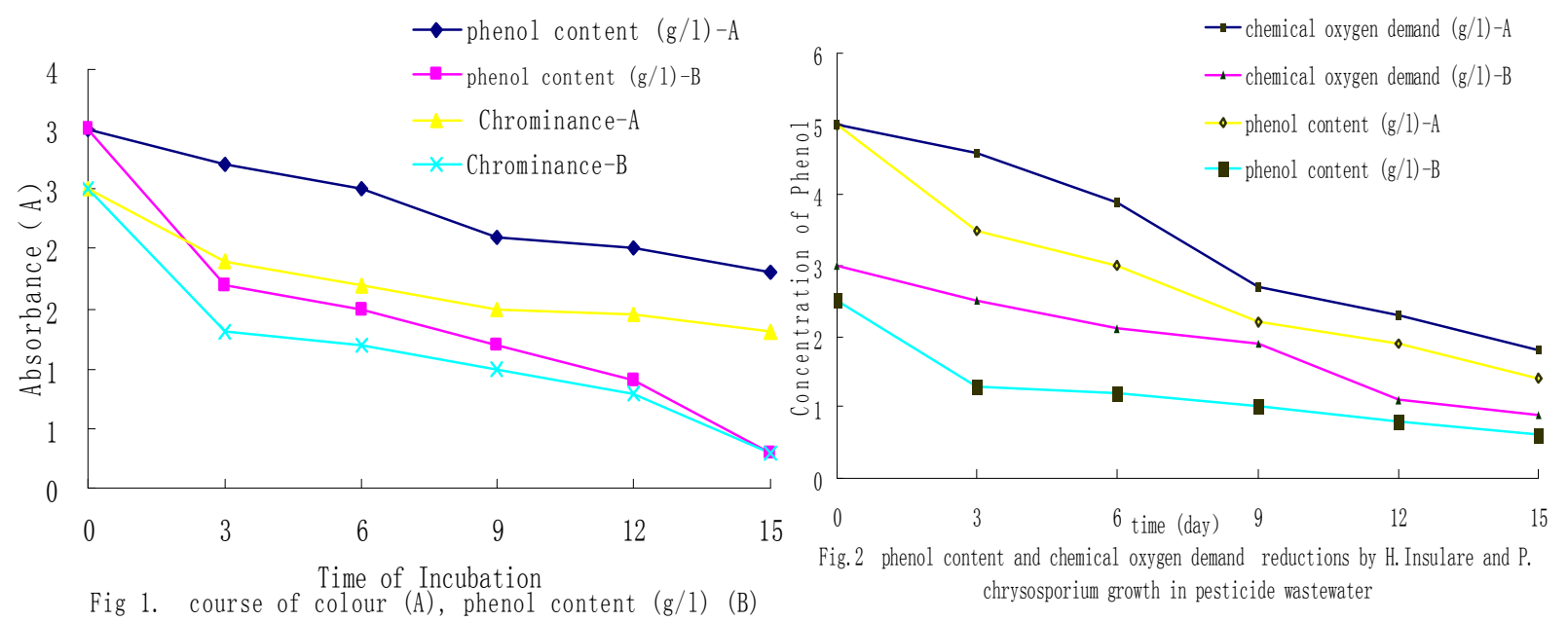

\section{H.Insulare treatment of pesticide wastewater}

The effect of fungal treatment on higher concentrated pesticide wastewater was investigated using the optimal conditions previously set up [7]. The results obtained when pesticide wastewater concentra -tion was increased from $20 \%$ to $50 \%$ are shown in Fig. 2. After 6 days of incubation, colors and phenol content reduction was about $50 \%$ in both culture conditions. 
As far as COD is concerned, its time course was close to linearity until after 15 days of fungal growth in $50 \%$ pesticide wastewater culture, whilst in $20 \%$ pesticide wastewater medium COD was almost unchanged between the $9^{\text {th }}$ and the $15^{\text {th }}$ days. It is worth to note that all the parameters tested reached similar values either for $20 \%$ or $50 \%$ pesticide wastewater after 15 days of treatment, although the initial values were very different. Furthermore, the time courses of ligninolytic enzyme production by H.Insulare grown on pesticide wastewater were analyzed (Fig.2). LiP, MnP and laccase activity production were monitored during H.Insulare incubation in $20 \%$ and $50 \%$ pesticide wastewater. LiP activity showed a maximum at about the 6th day and then decreased. On the other hand, MnP and laccase activities were almost undetectable till the 6th day and then increased from the 7th day onwards. No significant differences in enzyme production could be observed between the two conditions analyzed [8].

In order to investigate the performance of $H$.Insulare when larger volumes of pesticide wastewater are used, a 101 vessel filled with 81 of $20 \%$ pesticide wastewater was inoculated with $32 \mathrm{~g}$ (dry weight) of mycelium. The vessel was kept at room temperature under agitation and air was inflated for about $5 \mathrm{~h} /$ day. Absorbance at $395 \mathrm{~nm}$, phenol content and COD were followed during 15 days of treatment.

The decrease in all the parameters was slower than in the case of incubation performed in shaken flasks at $28^{\circ} \mathrm{C}$ in the dark. After 6 days of treatment, a decrease of only $15 \% \mathrm{~A}_{395}, 13 \%$ phenol content and $32 \%$ COD was observed; whilst a reduction of $93 \% \mathrm{~A}_{395}, 90 \%$ phenol content and $74 \%$ COD was obtained in 15 days.

Non-sterilized pesticide wastewater (20\%) was also treated with Ph. chrysosporium in the optimal treatment conditions previously described. After 15 days, the reductions in phenol content and COD were $55 \%$ and $69 \%$, respectively; in spite of this, no color reduction as well as no variation in the visible absorbance spectra was detected.

\section{Discussion}

Some authors have reported that nitrogen concentration and nature of the carbon source markedly influences pesticide wastewater decolonization by white-rot fungi [9]. Furthermore it has also been reported that $H$.Insulare $\mathrm{HD}$ is able to grow and decolorize diluted pesticide wastewater only in the presence of a complex medium containing nutrients, and vertebral alcohol as inducer of ligninolytic enzymes [10]. On the other hand, our results prove that the absence of added nutrients does not significantly reduce the ability of H.Insulare to decolorize pesticide wastewater. The optimal decolonization temperature for H.Insulare $\mathrm{M}_{1}$ is $28^{\circ} \mathrm{C}$; a temperature lower than that used for H.Insulare $\left(37^{\circ} \mathrm{C}\right)$. Furthermore, the optimal $\mathrm{pH}$ for pesticide wastewater treatment is in the range 4.0-5.0.

Since the $\mathrm{pH}$ of diluted pesticide wastewater is between 4.0 and 5.0, the process does not require any $\mathrm{pH}$ alteration of the effluent. Degradation of $20 \%$ or $50 \%$ pesticide wastewater, expressed as colour, phenol and COD removal, is almost the same after 15 days of fungal growth. Hence, not only is this fungus able to grow in 50\% pesticide wastewater as sole carbon source, but the degradation rate of the effluent increases in these cultural conditions [11]. This is not an obvious conclusion, taking into account that the concentration of pesticide wastewater negatively affects the decolonization process. It is worth noting that the achieved reduction of the parameters tested is enough to obtain a complete abatement of pesticide wastewater toxic effect on $B$. cereus bacteria. Moreover, scaling-up the fungal pesticide wastewater treatment resulted in a slower degradation recess, even if similar final results were obtained [12]. The observed difference in the rate of the processes can possibly be ascribed to a reduced aeration of the larger volume system respect to the shaken flask [13].

Since it has been reported that ligninolytic enzymes are involved in pesticide wastewater degrading process [14], ligninolytic enzyme production by $H$. Insulare was analyzed during pesticide waste -water treatment. Time courses of the production of three enzymatic activities (POX, MnP, LiP) are quite different; LiP activity reaches a maximum after 6 days of fungal growth and then decreases, whilst MnP and POX activities significantly increase from the 6th day onwards [15]. Because the 
most notable reduction in all parameters analyzed occurs during the first 6 days, it can be hypothesized that LiP enzymes play a key role in the degradation process. The isolated H.Insulare strain is therefore able to grow using diluted pesticide wastewater, as sole carbon source, and to notably reduce colors, phenol content and COD, thus proving to be a good candidate for the effective treatment of this waste water.

\section{Acknowledgements:}

This work was financially supported by the national science of Heilongjiang Province, project number: C201452.

\section{References}

[1] Turan I. Effect of olive mill wastewater discharge on the municipal wastewater treatment and feas -ibility of various pretreatment methods [D]. Msc. Thesis Izmir, Turkey: Dokuz Eylul University, 2004.

[2] Levin L, Herrmann C, Papinutti V L. Optimization of lignocellulolytic enzyme production by the white-rot fungus Trametes trogii in solid-state fermentation using response surface methodology [J]. Biochemical Engineering Journal, 2008, 39(1): 207-214.

[3] Gao D, Du L, Yang J, et al. A critical review of the application of white rot fungus to environme -ntal pollution control [J]. Critical reviews in biotechnology, 2010, 30(1): 70-77.

[4] Boonchan S, Britz M L, Stanley G A. Degradation and mineralization of high-molecular-weight polycyclic aromatic hydrocarbons by defined fungal-bacterial cocultures[J]. Applied and environmental microbiology, 2000, 66(3): 1007-1019.

[5] He S B, Wu G W, Deng H H, et al. Choline and acetylcholine detection based on peroxidase-like activity and protein antifouling property of platinum nanoparticles in bovine serum albumin scaffold[J]. Biosensors and Bioelectronics, 2014, 62: 331-336.

[6] Ilhan F, Kurt U, Apaydin O, et al. Treatment of leachate by electrocoagulation using aluminum and iron electrodes[J]. Journal of hazardous materials, 2008, 154(1): 381-389.

[7] Rizzo L. Bioassays as a tool for evaluating advanced oxidation processes in water and wastewater treatment [J]. Water research, 2011, 45(15): 4311-4340.

[8] Dang L, White D W, Gross S, et al. Cancer-associated IDH1 mutations produce 2-hydroxyglu -tarate [J]. Nature, 2009, 462(7274): 739-744.

[9] Ahmaruzzaman M. Adsorption of phenolic compounds on low-cost adsorbents: a review [J]. Advances in Colloid and Interface Science, 2008, 143(1): 48-67.

[10] Li Q, Xie J, Zhao L, et al. Optimization of fermentation conditions for laccase production by recombinant Pichia pastoris GS115-LCCA using response surface methodology and its application to dye decolorization[J]. BioResources, 2013, 8(3): 4072-4087.

[11] Abboud M M, Khleifat K M, Batarseh M, et al. Different optimization conditions required for enhancing the biodegradation of linear alkylbenzosulfonate and sodium dodecyl sulfate surfactants by novel consortium of Acinetobacter calcoaceticus and Pantoea agglomerans[J]. Enzyme and Microbial Technology, 2007, 41(4): 432-439.

[12] Larrosa-Guerrero A, Scott K, Katuri K P, et al. Open circuit versus closed circuit enrichment of anodic biofilms in MFC: effect on performance and anodic communities [J]. Applied microbiology and biotechnology, 2010, 87(5): 1699-1713.

[13] Neubauer P, Junne S. Scale-down simulators for metabolic analysis of large-scale bioprocesses [J]. Current opinion in biotechnology, 2010, 21(1): 114-121.

[14] Diez M C. Biological aspects involved in the degradation of organic pollutants [J]. Journal of soil science and plant nutrition, 2010, 10(3): 244-267.

[15] Kissi M, Mountadar M, Assobhei O, et al. Roles of two white-rot basidiomycete fungi in decolor -isation and detoxification of olive mill waste water [J]. Applied Microbiology and Biotechnology, 2001, 57(1-2): 221-226. 